\title{
Wacana Keadilan Sahabat Dalam Pandangan Ulama Klasik Dan Kontemporer
}

\author{
Lailiyatun Nafisah, Moh. Muhtador \\ Ilmu Hadis, Ushuluddin, IAIN Kudus-Indonesia \\ lailiyatunnafisah@gmail.com
}

DOI: http://dx.doi.org/10.29240/alquds.v2i2.429

Submitted: 2018-04-25 | Revised: 2018-10-26 |Accepted: 2018-11-13

\begin{abstract}
The writing explains the discourse of classical and contemporary scholars regarding friend justice, as something urgent in the narration of hadith. Argumentatively-dogmative this paper constructs the justice of friends in the classical ulama perspective, as well as the argumentative-dogmatic of contemporary scholars regarding friend justice in the narrative of the hadith as a comparison. This study is literary in nature which refers to qualitative methods that collect data from various Islamic literature that are considered to have relevance. So that it can be concluded that the religious scholars of the past had a friend's belief that they were just people guaranteed by the Prophet as human beings in their time, the Sunni argument was contradicted by contemporary scholars.
\end{abstract}

Keywords: justice, friend of the Prophet, classic, contemporary

\begin{abstract}
Abstrak. Tulisan menjelaskan wacana dari ulama klasik dan kontemporer mengenai keadilan sahabat, sebagai sesuatu yang urgen dalam periwayatan hadis. Secara argumentatif-dogmatif tulisan ini mengkonstruk keadilan sahabat dalam perspektif ulama klasik, serta argumentatif-dogmatif dari ulama kontemporer mengenai keadilan sahabat dalam periwayatan hadis sebagai perbandingan. Kajian ini bersifat literer yang mengacu pada metode kualitatif yang mengumpulkan data dari berbagai literatur keislaman yang dianggap mempunyai relevansi. Sehingga mendapatkan kesimpulan bahwa kalangan jumhur ulama dahulu mempunyai keyakinan sahabat adalah orang yang adil yang dijamin oleh Nabi sebagai manusia yang baik dalam masanya, argumen Sunni tersebut terbantah oleh ulama kontemporer.
\end{abstract}

Kata kunci: keadilan, sahabat Nabi, klasik, kontemporer 


\section{Pendahuluan}

Hadis merupakan sumber kedua setelah Alquran, oleh karenanya hadis memiliki perbedaan dari sisi periwayatannya. Jika Alquran sudah pasti adanya qath'i maka hadis bersifat dqaani wurud. Selain itu tidak semua yang disebut hadis adalah Mutawatir, terdapat hadis-hadis yang berstatus Ahad dan memerlukan kajian ulang terhadap keontetikan hadis Ahad tersebut baik dari sisi sanad maupun matannya.

Salah satu kajian hadis adalah pada sanadnya. Sanad memiliki mata rantai yang menjadi penghubung tersampainya hadis tersebut pada generasi setelahnya. Puncak dari mata rantai setelah Nabi Muhammad ialah sahabat. Fungsi sahabat sebagai transmiter dalam menerima hadis sangatlah penting, ${ }^{1}$ hal ini dikarenakan sabatlah yang menjadi saksi hidup atas hal ibkwal yang dilakukan oleh Nabi Muhammad SAW, bahkan tak jarang Nabi Muhammad selalu menyampaikan berbagai risalahnya kepada sahabat secara langsung lalu pada gilirannya nanti sahabat akan menyapaikan kepada sahabat lain yang tidak bisa mendengarkan atau menyaksikan secara langsung berita dari Nabi, sehingga terjadilah mata rantai. Kajian sanad menjadi hal yang sangat penting dalam menguji ke-shabihan hadis, terutama untuk mengetahui sisi keadilan maupun ke-dhabithan perawi hadis. $^{2}$

Dalam perkembangan hadis, tidak terlepas dari adanya masa Khulafaur Rasyidin. Utamanya masa adanya fitnah kubra, sehingga melahirkan beberapa permasalahan dengan hadis, salah satunya mengenai kritik terhadap sahabat Nabi.

Dalam pandangan Ulama klasik seluruh perawi hadis dalam serangkaian sanad hadis perlu dikritik untuk menentukan keadilan dan ke-dhobitannya. Namun, kajian terhadap perawi tersebut terkecuali untuk perawi tingkat pertama yaitu sahabat, hal ini dikarenakan adanya doktrin bahwasannya sahabat Nabi secara kolektif bersifat 'udul. ${ }^{3} \mathrm{Hal}$ tersebut dikarenakan hubungan persahabatan sahabat dengan Nabi Muhammad dan adanya teks-teks dari dalil naqli yang mendukung akan pendapat jumhur ulama tersebut. Sehingga, keadilan sahabat tidak perlu dilakukan kajian ulang dikarenakan sahabat bisa dikategorikan mendapat rekomendasi dari Allah mengenai keadilan mereka.

Namun, upaya mempertahankan doktrin 'adalah shababah ternyata mendapat kriktikan yang sangat tajam dari kalangan Ulama kontemporer pada

${ }^{1}$ Miftahul Asror and Imam Musbikin, Membedab Hadits Nabi SAW, (Yogyakarta: Jaya Star Nine, 2015), 194.

${ }^{2}$ M. Hasby ash Shiddiqy, Pokok- Pokok Ilmu Dirayah Hadits (Jakarta: Bulan Bintang, 1994), 18.

\footnotetext{
${ }^{3}$ Asror and Musbikin, Membedah Hadits Nabi SAW, 194.
} 
era modern dengan berbagai alasan yang dinilai logis. Karena syarat akan keontetikan sebuah hadis adalah salah satunya periwayat hadis bersifat adil lagi dhabith, apabila pada tingkat sahabat tidak dilakukan kajian ulang kritikannya, maka bisa dikatakan bahwasannya kaidah jarb wa ta'dil yang selama ini dibangun hanya sampai pada tingkat tabiin.

Berbagai pemikiran mangenai keadilan sahabat yang dahulunya disepakati oleh jumhur ulama sehingga sahabat tidak perlu untuk dikritik kembali, hal tersebut telah ditentang oleh sebagaian ulama modern, dengan mengatakan bahwasannya kajian sahabat tetap mebutuhkan kajian ulang dengan keadilannya. Salah satu ulama kontemporer yang memiliki pendapat tersebut adalah Abu Royyah.

Penulis menyadari bahwa artikel yang berkaitan dengan keadilan sahabat sudah banyak dikaji, seperti tulisan Nur Fadhilah di Jurnal Mutawatir yang berjudul Keadilan Sahabat Nabi dalam Perspektif Fuad Jabali. Adapun simpulannya ialah bahwasannya Fuad Jabali tidak memihak antara ahli hadis yang menganggap semua sahabat adil maupun kaum Mu'tazilah yang lebih mengedepankan logika mengenai keadilah sahabat, beliau lebih condong kepada hasil bahwa tidak semua sahabat adalah adil, beliau mengatakan bahwa sahabat memanfaatkan posisi yang tinggi dalam masyarakat muslin." ${ }^{.4}$ Letak perbedaan dengan kajian ilmiah ini pada spesifiknya, yakni lebih kepada argumentatif dari ulama klasik dan kontemporer mengenai keadilan sahabat, sehingga mampu mengahasilkan kesimpulan bahwasannya sahabat secara keseluruhannya adil, hal ini tentu bisa dibuktikan dengan dalil-dalil, baik naqli maupun aqli.

Tulisan Adnan dalam Jurnal Diroyah yang berjudul Reformasi Wacana Keadilan Sababat. Adapun kesimpulan berisi menganai pengertian sahabat yang berarti orang yang pernah berjumpa dengan Nabi maupun bergaul dengan Nabi Muhammad sampai akhir masa hidupnya, dikatakan adil dengan berbagai kriteria, seperti taat dalam beragama, menjaga diri dari perbuatan yang tidak terpuji dan menjaga kehormatan diri. Dalam tulisan Adnan menyebutkan bahwasannya semua sahabat adil, akan tetapi ada beberapa sahabat yang cacat ke-'adalahannya, yakni Abdulla bin Saba, Amru Ibn al- Ash bahkan Utsman bin Affan. ${ }^{5}$

Tulisan Muhammad Imran di Jurnal Aqlam yang berjudul Sababat Nabi saw dalam Perpektif Sunni dan Syi'ah (Pengarub pada Kesabihan Hadis). Adapun

\footnotetext{
${ }^{4}$ Nur Fadlilah, "Keadilan Sahabat Nabi Dalam Perspektif Fuad Jabali," Mutawatir: Jurnal Keilmuan Tafsir Hadith 2, no. 1 (2012): 110-27, doi:10.15642/mutawatir.2012.2.1.110-127.

${ }^{5}$ Adnan Adnan, "Reformulasi Wacana Keadilan Sahabat," Diroyab: Jurnal Studi Ilmu Hadis 1, no. 1 (2016): 1-6, doi:10.15575/diroyah.v1i1.2049.
} 
simpulannya bahwa ulama Syi'ah menolak pemikiran dari ulama Sunni yang mengatakan bahwa seluruh sahabat adil, bagi ulama Syi'ah ada beberapa klasifikasi mengenai sahabat yang adil dan tidak adil, oleh karenannya belum tentu yang dianggap adil oleh ulama Sunni juga dianggap adil oleh ulama Syi'ah, ataupun sebaliknya. ${ }^{6}$

\section{Pengertian Sahabat menurut Ahli Hadis}

Shahabah secara lughowi merupakan bentuk jamak dari kata shohib artinya "yang empunya dan menyertai".

Sahabat secara lughoh berasal dari kalimat "Shuhbah", yang memiliki arti "bersahabatnya orang satu dengan yang lainnya, baik lama atau tidak". Sehingga dapat dikatakan bahwasannya orang yang selalu bersama dengan yang lainnya dengan ukuran baik setahun, sebulan, sehari ataupun sesaat saja, bias disebut sebagai sahabat. ${ }^{8}$

Sedangkan menurut istilah ahli hadis, ialah:

$$
\text { كل مسلم راى رسول الله ص م }
$$

"setiap muslim yang dapat melihat Rasulullah SAW."

Banyak ulama yang memberikan pengertian tersendiri mengenai sahabat, diantaranya:

Imam Bukhari di dalam kitab Shahih-nya:

$$
\begin{aligned}
& \text { من صحب النبي ص م اوراه من الملسلين فهو من اصحابه وذكر الامام احمد من اصحاب }
\end{aligned}
$$

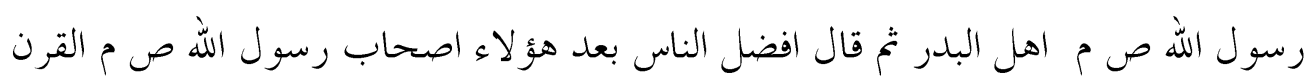

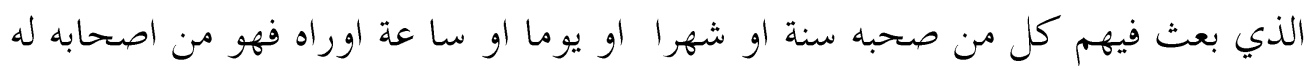

$$
\begin{aligned}
& \text { من الصحبة على قدر ما يصحبه و كانت سابقة معه و سمعه منه ونظره اليه }
\end{aligned}
$$

"Orang yang menyertai Nabi atau melihatnya dari antara orang- orang islam dipandang sahabatnya. Ahmad menerangkan bahwa di antara sababat-sababat Rasulullah itulah orang-orang yang turut bertempur dalam peperangan Badar. Kemudian dia berkata : Orang yang paling utama di antara manusia sesudah sababat-sahabat Rasulullah ialah orang-orang yang bidup dalam abad yang Rasulullah dibangkitkan dalam kalangan mereka, segala orang

6 Muhammad Imran, "Sahabat Nabi saw Dalam Perspektif Sunni dan Syi'ah (Pengaruhnya Pada Kesahihan Hadis)," Aqlam: Journal of Islam and Plurality 1, no. 1 (2016): 15-34.

${ }^{7}$ M. Hasby ash Shiddiqy, Sejarah Dan Pengantar Ilmu Hadis (Semarang: Pustaka Rizki Putra, 2002), 206.

${ }^{8}$ ash Shiddiqy, Pokok- Pokok Ilmu Dirayah Hadits, 141. 
yang melihat Rasulaullah dibangkitkan dalam kalangan mereka. Segala orang yang melihat Rasulullah baik setabun bebeapa bulan sehari ataupun sesaat ataupun hanya dapat melibatnya, digolongkan ke dalam golongan Sahabatnya. Dia berbak dapat menyertai Nabi dapat mendengar sesuatu keterangan Nabi dan dapat memandangnya".

Menurut Ibnu Hazm r.a:

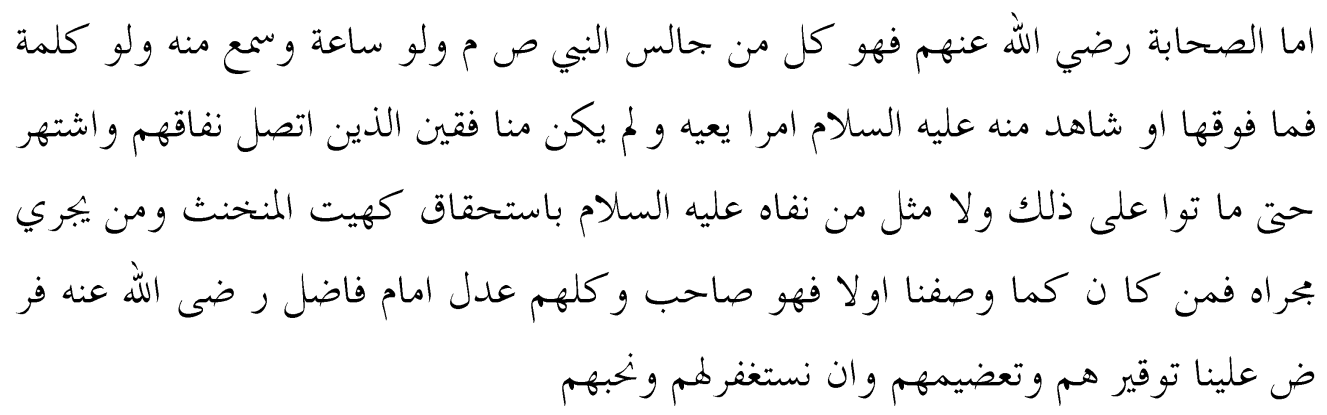

"Adapun Sababat Nabi ialah setiap orang yang dapat duduk bersama Nabi dalam satu majlis, walaupun sesaat dan dapat mendengar pembicaraan Nabi walaupun sekalimat atau dapat melibat sesuatu dari pada Nabi yang ia dapat memahaminya, sedang ia bukan dari orang munafik sehingga dia mati dalam keadaan itu dan tidak pula orang yang diusir oleh Nabi dari Madinah lantaran dia berbak diusir seperti Hait Al Mukharnats dan orang yang dipandang sama dengan dia. Maka setiap orang yang berada sebagai yang kami sifatkan di atas, dia dipandang shahabi semua mereka harus di padang adil lagi utama dan menjadi ikutan, wajib atas kita memuliakan mereka, memohon ampun untuk mereka dan mengasibi mereka. ${ }^{10}$

Al Waqidi berkata :

$$
\text { وروايت اهل العلم يقولون كل من راي رسول الله وقد ادرك الحلم فا سلم وعقل امر الدين }
$$

"Saya melibat abli ilmu mengatakan: "segala yang melihat Rasulullah sedang dia sudah sampai umur dan memeluk agama Islam serta memahami urusan agama dan menerimanya dengan merasa puas maka dia dalam pandangan kami dari orang yang menyertai Nabi walaupun dia hanya menyertai Nabi sepenuh bati". ${ }^{11}$

Menurut Al-Waqidi orang yang dapat melihat Rasulullah namun belum sampai cukup umur maka tidak termasuk golongan dari sahabat. Pendapat ini

${ }^{9}$ Ibid., 142. Bisa dilihat dalam Muqoddomah Ibnush Shalah: 118. Al Ba'itsul Hafits: 201. Tadribur Rawi: 396.,Fathul Mughits 4: 29. Tanqih 'Ulumil ahlil Atsar: 27

10 Ibid., 143.

${ }^{11}$ Ibid., 144. Bisa dilihat dalam Talqih (ahli Atsar hal 27. Fathul Mugits $4: 32$ ) 
dikritik oleh Al-'Iraqi bahwasannya adanya pembatasan mengenai sahabat dengan kecukupan umur merupakan pendapat yang ganjil.

Said Ibnu Musaiyab berkata :

$$
\text { الصحابة لانعدهم الا من اقام مع رسول اللّ ص م سنة او سنتين وغزو امعه غزوة اوغزوتين }
$$

"kami tidak memandang sahabat terkecuali orang yang bermukim bersama Nabi setahun atau dua tabun dan turut berperang bersama Nabi satu atau dua tabun". ${ }^{2}$

Ibnu Jauzi:

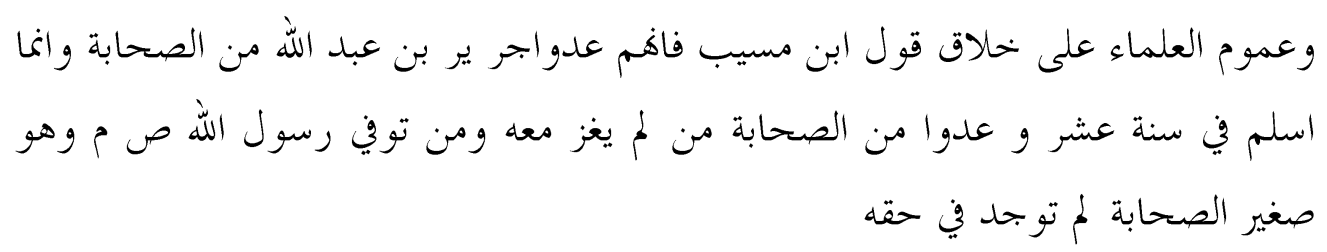

'Umum ulama tidak sepakat dengan Ibnul Musaiyab karena mereka menghitung Jarir ibn Abdullah al Bajali dari Shahabat Nabi padahal beliau memeluk Islam pada tabun $10 \mathrm{H}$ dan mereka menghitung dalam golongan para sababat orang yang tak pernab berperang bersama Nabi dan orang yang ketika Rasulullah wafat, dia masih kecil tidak pernah duduk. semajlis dengan Nabi, para ulama menggabungkannya dalam golongan sababat walaupun bakikat persababatan tidak ada padanya.",13

Ibnu Hajar:

$$
\begin{aligned}
& \text { واصح ما وقف عليه من ذلك ان الصحابي من لقي النبي مؤمنا به ومات علي الاسالم } \\
& \text { فيدخل فيمن لقيه من طالت بحالسته او قصرت ومن روى او لم يرو و من غزى معه او لم } \\
& \text { يغز و من راى رؤية و لمج يجالسه ومن لم يره لعارض كا لاعمى }
\end{aligned}
$$

"Pendapat yang paling shabih yang telah saya ketemukan ialah sababat orang yang menjumpai Nabi sedang diapun beriman kepada Nabi dan meninggal dalam keadaan Islam. Karenanya masuklab ke dalam golongan orang yang menjumpai Nabi orang yang lama duduk bersama-sama Nabi dan yang tidak, orang yang turut berperang bersama Nabi dan yang tidak, orang yang melihat Nabi dari jaub tapi tidak pernah duduk semajlis dengan Nabi dan orang yang pernah duduk bersama Nabi tetapi tidak dapat melihat Nabi karena buta". 14

Demikianlah pendapat dari berbagai jumhur ulama, sehingga dapat disimpulkan bahwasannya sahabi ialah orang yang bertemu dengan Nabi

\footnotetext{
12 Ibid.

${ }^{13}$ Ibid., 145. bisa dilihat Talqih Fuhum Ahli Atsar : 27

14 Ibid., 146.
} 
Muhammad SAW, baik melihat atau tidak (buta) dalam keadaan beriman sampai wafatnya, bergaul dengan Nabi baik lama ataupun sebentar.

Para ulama mengelompokkan para sahabat Nabi menjadi dua bagian, yakni kelompok sahabat Muhajjirin dan sahabat Anshor. Lalu sahabat yang hidup sezaman dengan Nabi akan tetapi tidak bertemu dengan Nabi Muhammad maka dinamakan Muhadramin. ${ }^{15}$

Mengenai jumlah sahabat menurut Ibnu Shalah dari Abu Bakar bahwa beliau menerangkan: "Tidak ada yang dapat menetapkan bilangan sahabat".

Abu Zur'ah mengatakan: “ ketikaNabi berhaji Wada beliau ditemani oleh empat puluh ribu sahabat. Ketika beliau ke Tabuk, beliau di temani oleh tujuh puluh ribu sahabat dan di waktu beliau wafat, sahabatnya berjumlah seratus empat belas ribu, yaitu terdiri dari mereka yang mendiami kota Madinah, Mekkah, orang-orang Arab dusun dan orang-orang yang menyaksikan Haji Wada'. Semua mereka melihat Nabi dan mendengarkan sabdanya di 'Arafah". ${ }^{16}$

Riwayat lain dari Al Bukhariy dari Ka'ab ibn Malik bahwasannya jumlah sahabat Nabi sangatlah banyak. Jumlah tersebut sebanyak 144.000 orang saat Rasulullah wafat. Diantara sahabat tersebut ada yang pernah berhaji Wada dengan Nabi Muhammad dan meriwayatkan hadis Beliau. Semua mereka melihat Nabi SAW dan mendengar hadis beliau di padang Arafah. ${ }^{17}$

\section{Awal Kemunculan Term Al-Shahabat Kulluhum 'Udul}

Sejara Islam telah mencatat bahwasannya dalam periode perkembangan hadis, telah melalui periode Khalifah empat atau masa Sahabat. Dimana para sahabat merupakan orang-orang yang telah mengikuti dan pernah berkumpul bersama saat Nabi masih hidup, dan masa tersebut merupakan sebaik-baiknya masa, lalu masa yang baik yaitu masa setelahnya, dan masa baik yang ketiga ialah setelahnya, hal ini telah diucapkan oleh Nabi Muhammad secara langsung. ${ }^{18}$

15 Tasmin Tangngareng, "Telaah Historis Terhadap Keadilan Sahabat," AL-FIKR: Jurnal Pemikiran Islam 14, no. 3 (2010): 447-60.

16 ash Shiddiqy, Pokok- Pokok Ilmu Dirayah Hadits, 156-57.

17 ash Shiddiqy, Sejarah Dan Pengantar Ilmu Hadis, 200.

${ }^{18}$ Dalam Shahih Bukhari, Nomor Hadis 3377. 
Ilmu Hadis pada masa perkembangannya pernah mengalami masa penyedikitan periwayatan yakni di masa Abu Bakar As-Shidiq, bahkan masa tersebut tidak banyak mempengaruhi perkembangan ilmu Kritik Hadis. Hal tersebut lantaran ada kekhawatiran tergabungnya hadis dengan Alquran. ${ }^{19}$ Sehingga, masa ini mereka berusaha menjauhi dari memperbanyak periwayatan dengan mendasarkan pada hadis Nabi. Masa Umar, apabila ada seseorang yang meriwayatkan seluruh hadis yang ia dengar, maka ia akan dianggap berbohong. Tindakan Umar ini tentu tanpa alasan, akan tetapi hal ini untuk menjaga supaya umat Islam pada saat itu tidak disibukkan dengan hadis sehingga melupakan Alquran dan juga menjaga agar tidak terjadi kebohongan dalam periwayatan. Hal itu disebabkan kamungkinan terjadi kesalahan dan lupa sangat besar. Pada masa sahabat, para Khalifah sangat ketat dan hati-hati dalam menerima periwayatan hadis, mereka tidak akan menerima periwayatan apabila hanya satu orang saja yang meriwayatkan, akan tetapi telah terbukti kebenarannya. Seperti Khalifah Abu Bakar yang memakai cara dengan meminta kepada periwayat hadis agar dalam meriwayatkan hadis menghadirkan saksi. ${ }^{20}$ Sedangkan Ali bin Abi Thalib meminta kepada periwayat untuk bersumpah atas kebenaran hadis tersebut. Bahkan di masa Umar, beliau melakukan keduanya untuk menjaga kehati-hatian dalam periwayatan hadis.

Masa Utsman bin Affan sebagai Khlaifah ketiga adalah masa pembukaan perlawanan bagi para sahabat, umat mulai membutuhkan sahabat, terutama sahabat kecil. Akhirnya, sahabat kecil bergerak mengumpulkan hadis dari sahabat-sahabat besar dan mulai banyak sahabat yang meninggalkan kediaman masing-masing untuk mencari hadis. Pada masa Ustman $(36 \mathrm{H})$ ini terjadi peristiwa yang besar, dengan terbunuhnya Khalifah, lalu terbunuhnya al-Husein bin Ali $(61 \mathrm{H})$, melahirkan berbagai kelompok sekte aliran-aliran dan sangat berpengaruh terhadap perkembngan Ilmu Krtikik Hadis. Hal tersebut dilakukan untuk memperoleh legitimasi dengan cara memalsukan hadis. ${ }^{21}$ Sehingga, ada

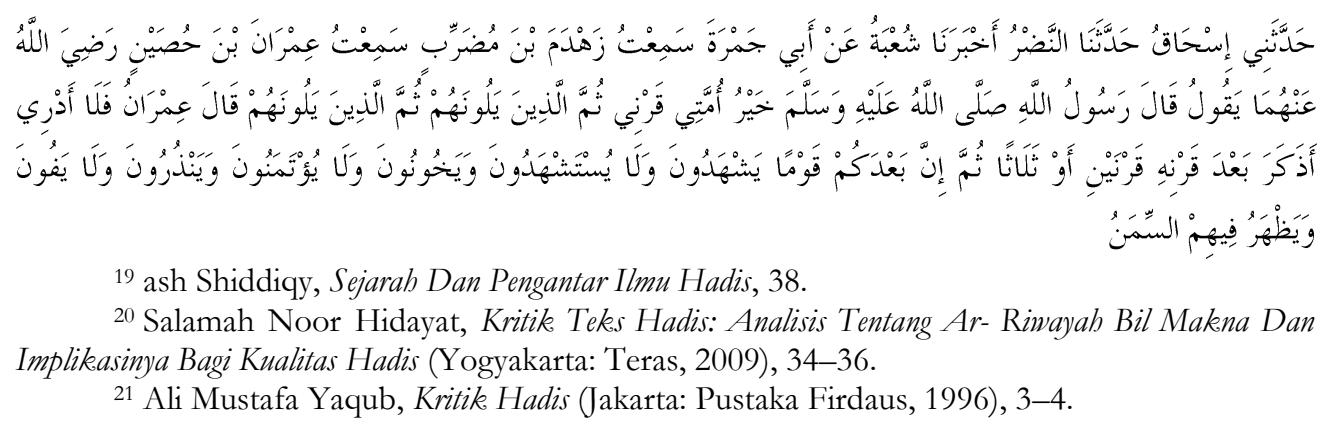


unsur dalam diri periwayat hadis yang berhubugan dengan keadilan dari periwayat hadis tersebut. Bisa dikatakan sejak saat itulah, muncul periwayat hadis pendusta untuk memalsukan hadis.

Imam Abu Muhammad bin Sirrin (33-110 H) memberikan isyarat bahwasannya semenjak terbunuhnya Ustman bin Affan $(36 \mathrm{H})$ telah terjadi pemalsuan hadis sebagai akibat dari fithnah kubra. Hal tersebut terjadi, karena berbagai alasan baik politik, pendekatan kepada Allah, Menodai Islam, menjilat penguasa, mencari rizmi, dan mencari popularitas. Padahal sebelumnya, dahulu setiap Nabi Muhammad bersabda dan umat Islam mendengarnya, bulu roma mereka seketika berdiri, akan tetapi saat setelah terjadi fitnah kubro, mereka selalu mempertanyakan dari mana asal hadis itu diperoleh. ${ }^{22}$

Sejak saat itulah ulama hadis tidak hanya bertumpu pada kritik matan saja, namun juga kritik sanad hadis. Kritik sanad hadis menjadi hal sangat penting, karena jika tanpa ada sanad maka setiap orang akan mengaku pernah bertemu dengan Nabi. Letak kejujuran inilah yang menjadi tugas para ulama hadis dalam meneliti keontetikan hadis. Sedangkan yang perlu dikritik adalah para periwayat hadis.

Sahabat adalah transmiter yang menerima hadis langsung dari Nabi Muhammad SAW. Tugas pembawa dan penyebar hadis ajaran Nabi membuat para ulama melindungi mereka sehingga melahirkan seluruh sahabat adil sebab keadilan mereka telah terjamin oleh Allah SWT. Pada abad inilah (akhir 3 awal 4) para ulama hadis membuat konsep "Al shahabat kullubum 'udul".

\section{Konsep 'Adalah}

Salah satu syarat diterimanya hadis adalah adanya keadilan dari rawi tersebut. Menurut sebagian ulama 'adl merupakan jiwa malakah dalam diri seseorang disertai dengan sikap takwa serta menjaga muru'ah. ${ }^{23}$

Kata Adil berasal dari Bahasa Arab, yaitu akar kata dari 'adala, ya'dilu, 'adlan, 'udulan, 'adalatan yang berarti meluruskan, menyamakan, berbuat adil,

${ }^{22}$ Ibid., 82-85.

${ }^{23}$ Umma Farida, Paradigma Periwayatan Dan Kritik Matan Hadis Perspektif Jamal Al- Banna (Yogyakarta: Idea Press, 2009), 45. 
mneyekutukan, menyimpang, berpaling kepada, berubah pendapatnya, meluruskan, mengimbangi. ${ }^{24}$

Secara Lughah, ialah "maqbulusy Syahadab" yaitu orang yang diterima kesaksiannya. ${ }^{25}$ Adil dalam Alquran sangat berkaitan dengan sikap yang seimbang dan menengahi. Kesaksian bisa diberikan secara adil karena sikap tersebut, hal tersebut dikarenakan dilakukan dengan sikap yang tenang dan bebas dari sikap yang berlebihan. Sikap adil ini berkaitan dengan sikap amanah dan jujur. $^{26}$

Kata Adil memiliki beberapa arti, antara lain: menghadapi ketidakadilan, menghadapi kemaksiatan dan kefasikan serta kemaksiatan, dan tercegah artinya tabiat untuk menjauhi hal-hal yang telah dilarang, terjaga dari dosa dan kesalahan dengan pertolongan Allah. ${ }^{27}$

Secara terminology, kata Adil memiliki banyak definisi. Menurut pakar Fuqoha, adil adalah menempatkan sesuatu pada tempatnya dan sesuai porsinya, seperti pada pembagian warisan. Menurut ulama Muhaddisin orang yang tidak pernah melakukan dosa besar serta menjauhi dosa-dosa kecil dinamakan Adil. ${ }^{28}$ Seseorang yang meriwayatkan hadis harus memiliki sifat Adil, karena sifat ini yang akan menentukan diterima atau tidaknya riwayat tersebut. Bahkan menurut Musthofa Azami jika berhubungan dengan keadilan maka tidak ada toleransi, berbeda jika berhubungan dengan ke-dhobitan meskipun pada level yang paling bawah tetap saja mendapat toleran. yaitu: ${ }^{29}$

Jumhur ulama memberikan kriteria terhadap 'adil sebagai faktor penentu,

\section{Islam}

Keislaman menjadi syarat utama dalam penyampaian hadis, meskipun saat menerima hadis Islam tidak menjadi faktor utama. Namun, jika seorang perawi ingin menyampaikan atau meriwayatkan hadis maka harus dalam kondisi Islam.

24 Ahmad Warson Munawir, Al-Munawir: Kamus Arab-Indonesia (Jakarta: Pustaka Progresif, 1984), 905.

25 ash Shiddiqy, Pokok- Pokok Ilmu Dirayah Hadits, 32.

26 Tangngareng, "Telaah Historis Terhadap Keadilan Sahabat," 448.

27 Asror and Musbikin, Membedab Hadits Nabi SAW, 182-87.

${ }^{28}$ Imran, "Sahabat Nabi saw Dalam Perspektif Sunni dan Syi'ah," 102-3.

${ }^{29}$ ash Shiddiqy, Pokok-Pokok Ilmu Dirayah Hadits, 32. 
Hal tersebut dikarenakan hadis merupakan sumber ajaran islam yang kedua setelah Alquran, sehingga orang yang tidak beragama Islam tidak bisa diterima periwayatannya sebagai ajaran Islam.

Argumen yang digunakan oleh ulama dalam menetapkan status Islam sebagai syarat keadilan sahabat ialah Alquran surat al-Hujarat ayat 6:

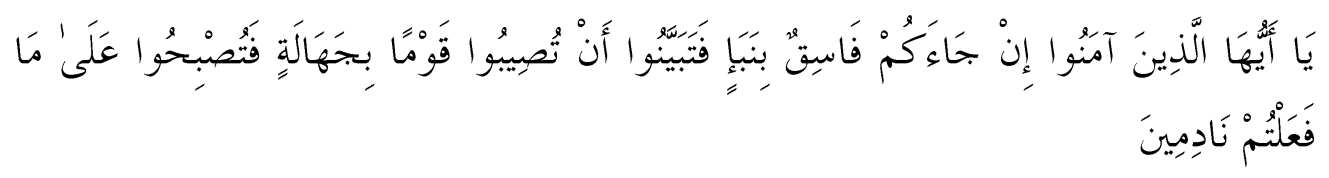

"Hai orang-orang yang beriman, jika datang kepadamu orang Fasik membawa suatu berita, Maka periksalah dengan teliti agar kamu tidak menimpakan suatu musibah kepada suatu kaum tanpa mengetabui keadaannya yang menyebabkan kamu menyesal atas perbuatanmu $i t u$ " ${ }^{30}$

Maksudnya, bahwasannya pendapat orang yang fasik saja tidak boleh bisa di terima apalagi pendapat orang yang kafir.

\section{Taklif atan Mukalaf}

Mukalaf disini ialah orang yang sudah memiliki tanggung jawab. Hal ini tidak memungkinkan bagi orang yang gila, lupa dan anak-anak untuk meriwayatkan hadis. Karena, mereka lepas dari tanggung jawab. Dikarenakan seseorang tidak bisa dituntut terhadap yang diperbuat maupun yang dikatakan apabila ia belum atau tidak memiliki tanggung jawab.

\section{Takwa}

Takwa adalah melakukan perintah agama Allah dan menjauhi larangan. Orang yang melaksanakan ketentuan agama Allah akan merasa selalu diawasi oleh Allah, sehingga ia tidak akan berani melakukan hal yang melanggar ketentuan agama Allah, misalnya melakukan kebohongan saat meriwayatkan hadis. Sekiranya terdapat kekeliruan dalam menyampaikan berita maka hal tersebut bukanlah disengaja akan tetapi diluar kemampuannya.

Orang yang tidak takwa atau melaksanakan ketentuan agama Allah tidak bisa dipercaya perihal beritanya termasuk dalam hal ini adalah hadis Nabi. Karena orang tersebut dengan mudah membuat berita yang palsu, terlebih berita yang menyangkut mengenai Hadis Nabi..

30 Al-Quddus, Al-Qur'an Tarjamah (Kudus: Mubarokatan Toyyibatan, n.d.), 515. 


\section{Sejabtera dari sebab-sebab kefasikan dan yang merusak muru'ah.}

Memelihara muru'ah maksudanya ialah, menjaga harga diri serta meninggalkan segala hal yang mengakibatkan rusaknya harga diri dan menuruti aturan yang benar. Seperti: kencing di jalan, mencaci maki atau menghina orang lain. Sifat-sifat inilah yang merusak moral sehingga riwayatannya sukar untuk diterima.

Muru'ah termasuk wujud nilai yang berkembang dalam masyarakat. Jika seseorang tidak bisa memelihara muru'ah-nya mengakibatkan tidak akan dihargai oleh masyarakat. Orang yang tidak dihargai oleh masyarakat kecenderunagnnya melakukan berbagai tindakan kompensasi yang menjadikan ia memperoleh perhatian masyarakat. Bisa jadi, salah satu bentuknya dengan melakukan penyampaian berita kebohongan.

Apabila faktor-faktor diatas sudah terpenuhi, maka pada diri seseorang sudah dianggap adil dan jujur. Karena ia akan senantiasa terpanggil untuk melakukan kejujuran dan menghindari dusta.

\section{Faktor Penghapus Keadilan}

Sifat-sifat yang bisa menyebabkan gugurnya keadilan seseorang ialah: ${ }^{31}$

\section{Dusta}

Dusta disini berarti orang yang telah meriwayatkan hadis pernah meriwaytkan hadis dengan dusta atau membuat hadis maudhu'/palsu. Meskipun hal tersebut dilakukan hanya sekali saja, maka tidak akan diterima hadisnya, meskipun ia bertaubat. Akan tetapi jika orang tersebut berdusta dalam menjadi saksi palsu, lalu ia bertaubat maka diterima riwayatannya.

Para Ulama telah menetapkan ijmak bahwsannya tidak diperbolehkan menerima suatu hadis dari orang yang berdusta terhadap Rasul, dan orang yang berdusta terhadap Rasul maka termasuk suatu dosa besar.Namun, para ulama berselisih pendapat tentang kearifan orang tersebut. Juga mereka berselisih tentang penerimaan taubatnya. Mengenai diterima atau tidaknya taubat orang yang berdusta dalam hadis, banyak ulama yang berbeda pendapat, ada yang mengatakan diterima taubatnya ada yang mengatakan tidak diterima dengan dalih bahwasannya berdusta terhadap Rasul merupakan dosa besar.

\footnotetext{
31 ash Shiddiqy, Sejarah Dan Pengantar Ilmu Hadis, 177-81.
} 


\section{Tertudub Dusta}

Yang dimaksud tertuduh berdusta ialah, bahwasannya perawi tersebut telah terkenal berdusta dalam pembicaraan, namun yang berhubungan dengan periwayatan hadis belum terbukti berdusta.

Biasanya hadis yang diriwayatkan oleh orang ini disebut sebagai hadis Matruk. Apabila bertaubat maka hadisnya diterima. Namun juga terdapat perbedaan pendapat dikalangan jumhur ulama, bahwasannya orang yang telah diketahui tertuduh berdusta walaupun sekali saja ditolak hadisnya.

Namun, ada sebagian ulama yang membolehkan menerima hadis dari orang yang hanya satu kali berdusta kemudian bertaubat.

\section{Fusuq}

Fusuq disini adalah dalam hal amal, bukan dalam hal I'tiqad. Jika fusuq dalam hal I'tiqad maka termasuk bid'ah.

Ibnu Katsir berkata " Orang yang diterma periwayatannya, yang percaya lagi kokoh ingatannya terhadap riwayatnya ialah orang Islam, yang berakal, telah sampai umur, bersih dari sebab yang memfasikkan, bersih dari pekerjaan yang menyalahi muru'ah (kemanusiaan), ia seorang yang berhati-hati, bukan pelengah, ia hafal riwayatnnya, jika ia riwayatkan hafalannya, dan ia memahamkan apa yang ia riwayatkan, jika ia riwayatkan secara makna, jika cedera sesuatu syarat tersebut di atas padanya ditolak lah hadisnya".

\section{Jahalah atau Tidak Terkenal}

Alasan orang jahalah atau tidak dikenal namanya dijadikan sebagai argumen gugurnya keadilan karena orang jahalah nama dan pribadinya tidak diketahui, sehingga keadannya pun tidak diketahui, jika keadannya tidak diketahui maka dipercaya atau tidaknya akan sulit untuk diketahui.

Orang yang namanya tidak disebut berarti dinamakan hadis Mubham. Hadis Mubham dibisa diterima, kecuali pada tingkatan sahabat.

\section{Bid'ah}

Yang dimaksud di sini ialah memiliki I'tiqad yang menyalahi agama (Alquran dan Sunnah) dengan tidak disengaja, lantaran salah pengertian. Jika bid'ah ini disengaja maka dinamakan kufur. 
Hadis yang diriwayatkan oleh orang yang bid'ah menurut jumhur ulama maka tertolak. Namun sebagian ahli hadis lain mengatakan bahwasannya jika yang mengatakan itu orang yang benar, jujur, diterima. Ada sebagian lagi yang mengatakan "Apabila ahli bid'ah meningkari sesuatu hukum, yang mutawatir yang semua kita mengetahui bahwa yang diingkari itu dari agama, barulah riwayatnya tertolak. Apabila tidak demikian, diterima riwayatnya. Meskipun dikafirkan oleh orang-orang yang menentangnya asal saja dia itu kokoh ingatannya dan mempunyai sifat takwa serta tidak berdusta."

Sehingga pendapat akhir, apabila ia seseorang yang mempropagandakan bid'ah-nya, maka ia tertolak. Dan kalau tidak, kecuali jika riwayatnya menguatkan bid'ah-nya.

\section{Keadilan Sahabat Menurut Ulama Klasik}

Jumhur Ulama klasik telah menyetujui bahwasannya semua sahabat itu Adil. Para sahabat memiliki keistimewaan tersendiri. Hal tersebut dibuktikan dengan argumen yang sangat kuat melalui berbagai dalil Alquran maupun hadis yang menerangkan keadilan tersebut. Seperti dalam surah Al-Imran: (110), AtTaubah: (100), Al-Fath: (18), Al-Hasy: (8-9), dan Al-Baqarah: (143). Yang kesemuanya menerangkan kewajiban menghormati sahabat-sahabat Nabi SAW, bahkan segala berita yang dinyatakan oleh sahabat harus diterima dan dibenarkan, karena sahabat dinilai memiliki integritas pribadi, kejujuran dan amanah. Memang bisa saja mereka lupa atau keliru, namun hal tersebut tidak mengurangi kejujuran mereka. Oleh karenanya, apabila ada informasi mereka yang berbeda dengan informasi yang lebih kuat (dalam hal ini bisa berarti riwayat), maka ketika itu informasi yang berbeda tersebut di tolak, tapi bukan dengan alasan bahwa para sahabat Nabi SAW, itu berbohong lantaran keliru. Memang semua manusia dapat salah dan lupa. ${ }^{32}$

Keistimewaan sahabat lain adalah karena keimanan dan amal-amal saleh mereka. Seandainya tanpa iman dan amal saleh, tentu saja mereka tidak terpuji dan tidak wajar untuk diikuti. Atas dasar tersebutlah, sehingga Allah meridhai mereka bahkan Allah menyediakan surga bagi mereka.

Bahkan ada beberapa hadis yang menerangkan keadilan sahabat. Diantaranya:

${ }^{32}$ M. Quraish Shihab, Tafsir al-Mishbah: Pesan, Kesan, dan Keserasian al-Qur'an (Tangerang: Lentera Hati, 2009), 5, 698-99. 


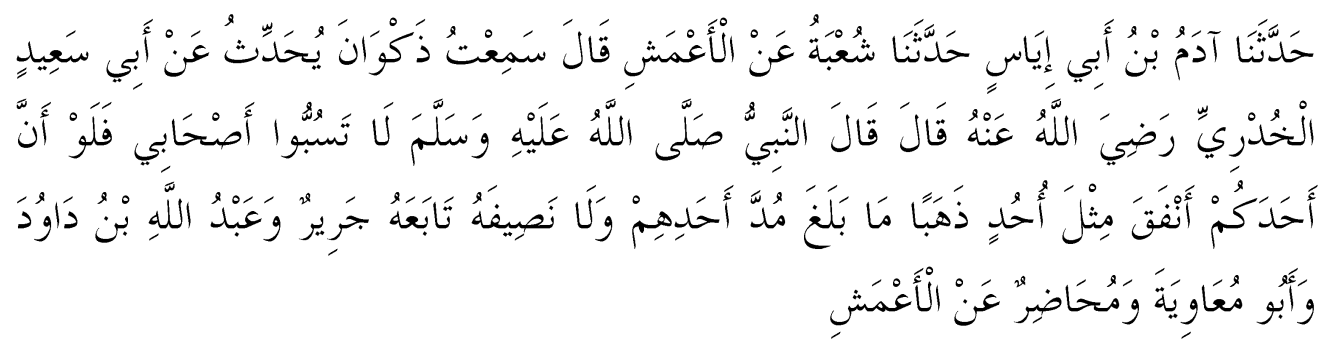

Telah bercerita kepada kami Adam bin Abu Iyas telah bercerita kepada kami Syu'bah dari Al A'masy berkata, aku mendengar Drakwan bercerita dari Abu Sa'id Al Khudriy radliallabu 'anhu yang berkata; Nabi shallallabu 'alaibi wasallam bersabda: "Janganlah kealian mencela sababat-sababatku. Seandainya salab seorang dari kalian menginfakekan emas sebanyak bukit Ubud, tidak akan ada yang menyamai satu timbangan (pahala) seorangpun dari mereka, juga tidak akan sampai setengabnya". Hadits ini diikeuti pula oleb Jarir, Abdullah bin Daud, Abu Mu'awiyah dan Muhadlir dari Al A'masy. ${ }^{33}$

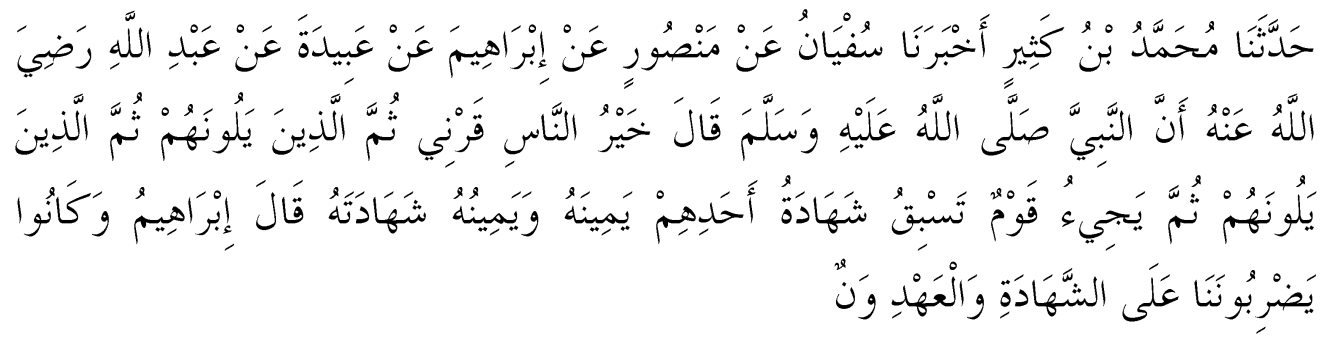

Telah bercerita kepada kami Mubammad bin Katsir telah mengabarkan kepada kami Sufyan dari Manshur dari Ibrahim dari 'Abidah dari Abdullah radliallabu 'anbu babwa Nabi shallallabu 'alaibi wasallam bersabda: "Sebaik-baik manusia adalah orang-orang yang bidup pada zamanku (generasiku) kemudian orang-orang yang datang setelab mereka kemudian orang-orang yang datang setelah mereka. Kemudian akan datang suatu kaum yang persaksian salah seorang dari mereka mendabului sumpabnya dan sumpabnya mendabului persaksiannya". Ibrabim berkata; "Dabulu, mereka (para sababat) mengajarkan kami tentang bersaksi dan memegang janji ketika kami masih kecil". (Mereka memukul kami bila melanggar perjanjian dan persaksian)". Berdasarkan dalil naqli dan aqli tersebutlah yang berisi keutamaan sababat dan larangan untuk menjelek-jelekekan sababat, menjadikan adanya argumen bahwasannya seluruh sahabat adalah adil. ${ }^{34}$

Hal ini telah disepakati oleh berbagai ulama Sunni seperti Ibn Hazm, alGhazali, al-Khatib al Bagdadi, Ibn Katsir dan as-Syuyuti, karena dalil-dalil baik aqli maupun naqli, sehingga menuai kesepakatan bahwasannya as-shahabat

33 Abi Abdillah Muhammad bin Ismail Al-Bukhari, Al-Jami' Al-Shabih (Mesir: Maktabah Salafiyah, 1403), hadis nomor 3397.

${ }^{34}$ Ibid., hadis nomor 3378. 
kulluhum udul, karena kemuliaan sahabat tersebut, bahkan menurut As Syuyuti keadilan tersebut baik yang terlibat dalam peristiwa fitnah kubro maupun tidak. Keadilan tersebut tidak perlu diteliti karena status mereka sebagai pembawa syariat secara lngsung dari Nabi. Jika seandainya saja ditolak maka syariat Islam akan berhenti pada zamannya Nabi Mahammmad SAW. ${ }^{35}$

Selain dalil Alquran juga terdapat dalil hadis yang dijadikan sebagai landasan ulama Sunni dalam menilai keadilan sahabat.

عن ابي سعيد الخذري رضي الله عنه قال قال رسول الله ص م لاتسبوا اصحابي فلو ان

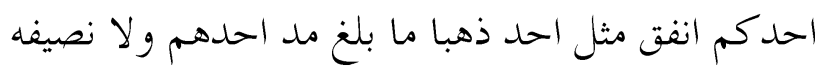

"Dari Abu said al- Khudry r.a berkata: Rasulullah saw, telah bersabda janganlah kalian mencaci maki para sababatku. Sekiranya diantara kalian bersedekah emas sebesar bukit Ubud, niscaya sedekahmu itu tidak akan sampai menyamai sepucuk atau separo dari para sababatku."

\section{Keadilan Sahabat Menurut Ulama Kontemporer}

Pemikiran dari Jumhur Ulama mengenai keadilan sahabat dengan term "Ashahabat Kullubum 'udul" ternyata menuai perbedaan pendangan dari sejumlah pemikir Modern, dengan berbagai alasan.

\section{Muhammad Abu Rayyah}

Nama aslinya adalah Muhammad Abu Rayyah, dilahirkan pada tahun 1889. Beliau termasuk salah satu ulama kontemprer yang sangat gigih dalam membahas mengenai keadilan sahabat adalah Muhammad Abu Rayyah. Seperti pandangan beliau mengenai hadis yang diriwayatkan oleh Abu Hurairah:

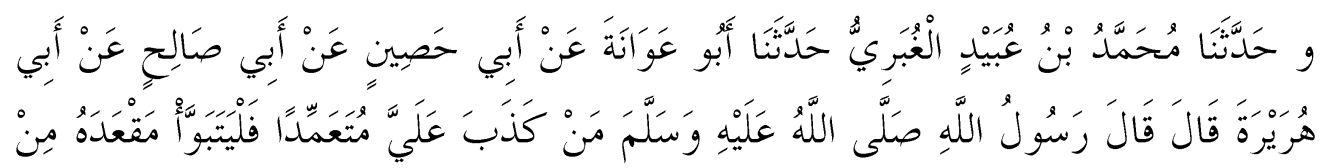

Telah menceritakan kepada kami Mubammad bin Ubaid al-Ghubari telah menceritakan kepada Kami Abu Awanah dari Abu Hashin dari Abu Shalih dari Abu Hurairah dia 
berkata, "Rasulullah shallallahu 'alaibi wasallam bersabda: "Barangsiapa berdusta atas namaku maka hendaklah dia menempati tempat duduknya dari neraka."

Menurut Abu Rayyah hadis tersebut menunjukkan bahwasannya suatu kebohongan terjadi dikalangan sahabat. Oleh karenanya, seluruh hadis harus diuji dan para sahabat pun tidak bisa terlepas dari pengujian tersebut karena pemalsuan pernah terjadi secara besar-besaran.

Muhammad Abu Rayyah mengatakan dalam kitabnya "Apabila jumhur menetapkan bahwa semua sahabat itu adil, tidak menerima jarh ataupun ta'dil sebagaimana diterima oleh seluruh perawi, maka mereka telah menganggap para sahabat tersebut terjaga (ma'shum) dari kesalahan dan lupa. Pada dasarnya para muhaqqiq tidak menetapkan bahwa seluruh sahabat itu adil , bahkan diantara mereka ada yang berpendapat sebagaimana yang dikatakan oleh AlamahalMukhilbi, sebenarnya hal itu merupakan mayoritas sahabat, bukan keseluruhan karena pada hakikatnya sahabat itupun juga manusia yang bisa terkena salah dan lupa dan juga terjadi hawa nafsu sebagaimana manusia lainnya. Mereka menegaskan bahwasannya sahabat juga manusia sehingga salah dan lupa pasti juga terjadi. Konsekuensinya mereka bisa dikritik dalam yang terjadi pada masanya. Diantara mereka ada yang munafik, pendusta khianat, menyebar fitnah dalam perang dan lainnya.

Muhammad Abu Rayyah menyalahkan prinsip yang dipengang oleh ulama pada umumnya yang menyatakan bahwasannya setiap perawi harus dikritik kredibilitasnya pada setiap tingkatan, akan tetapi berhenti ketika sampai pada tingkat sahabat. Argumen yang dijadikan Abu Rayyah patokan adalah:

1. Hadis tersebut memperlihatkan bahwasanya ada ketidakpercayaan Nabi Muhammad kepada sahabat. Oleh karenanya hadis tersebut sebagai peringatan sahabat karena pada saat itu ada sahabat yang melakukan dusta.

2. Konflik antara para sahabat, misalnya saja: Ketika Aisyah mendengar bahwa Ibn Umar menyampaikan hadis mengenai orang yang meninggal akan terkena azab jika keluarga mayit menangisi. Lalu Aisyah memberikan komentar bahwa hadis tersebut bertentangan dengan dalil Alquran.

3. Mengenai kasus ikhtisar al Hadis yakni praktik periwayatan hadis oleh sahabat tertentu dimana sahabat tersebut melebihi batas kewajaran, hal ini menjadi

\footnotetext{
${ }^{36}$ Muslim ibn Hujjaj Al-Qusyri Al-Naisabury, Shabih Muslim (Beirut: Dar Ihya' al-Kutub al-'Arabiyah, n.d.), hadis nomor 4.
} 
menarik perhatian para kritikus hadis untuk kajian yang lebih, bahkan mudah tertuduh sebagai sahabat yang ceroboh dan tidak jujur dalam menyampaikan hadis. Seperti sahabat Abu Hurairah, beliau bersama Nabi tiga tahun namun beliau banyak meriwayatkan hadis.

Bahkan dalam bukunya yang berjudul "Qisah al- Hadis al- Muhammadi: Syaikh al-Madirah (Kisah Hadis Muhammad Syaikh al- Madirah). ${ }^{37}$ Abu Rayyah menyoroti Abu Hurairah sebagai sahabat yang jago makan kue (Syaikh alMudirab), dengan alasan Abu Hurairah masuk Islam karena cintanya pada duniawi, harta bukan karena ikhlas.

Abu Rayyah menyoroti hadis yang diriwayatkan oleh Abu Hurairah:

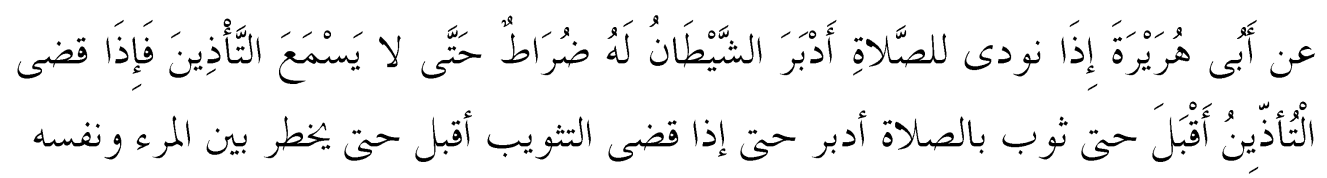

Dari Abu Hurairah, apabila diserukan shalat maka setan pun lari sampai terkentut-kentut sehingga ia tidak mendengar adzan, apabila telah selesai adzan maka dia datang. Kemudian, ketika ia kembali melakukan shalat maka setan pun lari, apabila selesai seruan shalat ia kembali sehingga jelas sama antara orang tersebut dan dirinya.

Abu Hurairah dicurigai oleh Muhammad Abu Rayyah karena beliau meriwayatkan hadis yang melebihi batas kewajaran. Bahkan Abu Hurairah adalah seorang korupsi, hal ini dilakukan oleh Abu Hurairah ketika diurus oleh Nabi Muhammad ke Bahrain dengan maksud menyebarkan agama Islam serta menerangkan persoalan-persoalan hidup ${ }^{38}$

Ketika masa khalifah Umar bin Khatab, sahabat Abu Hurairah menjadi seorang gubernur di Bahrain. Pernah disuatu hari Abu Hurairah datang dengan membawa sepuluh dirham. Melihat hal itu, Umar berkata kepadanya, "Engkau menguasai harta ini untuk dirimu, hai musuh Allah dan musuh kitab-Nya?" Abu Hurairah menjawab, "(Harta itu dari) kuda yang beranak, penghasilan budak milik saya, dan pemberian-pemberian yang saya terima secara berturut-turut." Kemudian mereka melihat dan mereka menyatakan apa yang ia ucapkan. Kritik Muhammad Abu Rayyan terhadap Abu Hurairah yang lainya ketika Abu Hurairah menjabat gubernur di Bahrain, telah melakukan pencurian uang

${ }^{37}$ Sochimin Sochimin, "Telaah Pemikiran Hadis Mahmud Abu Rayyah Dalam Buku “Adwa' 'Ala Al-Sunnah Al-Muhammadiyah"," HUNAFA: Jurnal Studia Islamika 9, no. 2 (2012): 271-300, doi:10.24239/jsi.v9i2.77.271-300.

38 Asror and Musbikin, Membedab Hadits Nabi SAW, 208-9. 
(korupsi) sepuluh ribu dirham, kemudian Umar memberhentikan dan memukul Abu Hurairah dengan cambuk sampai berdarah. ${ }^{39}$

Selain Abu Hurairah, sahabat Ka'ab al-Akhbar dan Wahab bin Munabah pun menjadi sorotan Abu Rayyah. Wahab bin Munabah dituduh sebagai seorang pendusta dan pembuat hadis palsu (maudbu'), hal tersebut berkaitan dengan riwayat Isra'iliyyat yang dibawakan Wahab yang dalam matannya banyak mengandung kejanggalan. Namun, diantara sahabat-sahabat yang paling disoroti oleh Abu Rayyah ialah Abu Hurairah. Hal tersebut wajar apabaila mengingat Abu Hurairah sebagai orang yang meriwayatkan hadis paling banyak.

\section{Kesimpulan}

Masalah keadilan sahabat menjadi polemik tersendiri dalam kajian Ilmu Hadis. Hal ini lahir karena adanya perbedaan prinsip metodologis antara ulama klasik dengan ulama kontemporer mengenai keadilan sahabat. Di kalangan ulama klasik saja keadilan sahabat sudah tidak perlu diragukan lagi dan tidak pula mendapat kritikan dalam menilai setiap perawi. Akan tetapi pemahaman tersebut tidak berhenti sampai disitu, meskipun berasal dari satu aliran. Namun, di kalangan ulama kontemporer pun ada tokoh yang mempertanyakan ulang konsep "adalah shahabat", sehingga meskipun berada pada tingkat sahabat, namun perlu juga mendapat kritikan dengan melalui kritik sanad hadis layaknya perawi lainnya. Seperti tokoh Muhammad Abu Rayyah, dengan kritikan tajamnya yang dilontarkan kepada Abu Hurairah sebagai bentuk perlunya dilakukan kajian ulang terhadap keadilan sahabat dan menerapkan prinsip jarb wa ta'dil meskipun dikalangan sahabat.

\section{Bibliografi}

Adnan, Adnan. "Reformulasi Wacana Keadilan Sahabat." Diroyab: Jurnal Studi Ilmu Hadis 1, no. 1 (2016): 1-6. doi:10.15575/diroyah.v1i1.2049.

Al-Bukhari, Abi Abdillah Muhammad bin Ismail. Al-Jami' Al-Shabih. Mesir: Maktabah Salafiyah, 1403.

Al-Naisabury, Muslim ibn Hujjaj Al-Qusyri. Shabih Muslim. Beirut: Dar Ihya' alKutub al-'Arabiyah, n.d.

\footnotetext{
${ }^{39}$ Sochimin, "Telaah Pemikiran Hadis Mahmud Abu Rayyah.”
} 
Al-Quddus. Al-Qur'an Tarjamah. Kudus: Mubarokatan Toyyibatan, n.d.

Asror, Miftahul, and Imam Musbikin. Membedah Hadits Nabi SAW,. Yogyakarta: Jaya Star Nine, 2015.

Fadlilah, Nur. "Keadilan Sahabat Nabi Dalam Perspektif Fuad Jabali." Mutawatir: Jurnal Keilmuan Tafsir Hadith 2, no. 1 (2012): 110-27. doi:10.15642/mutawatir.2012.2.1.110-127.

Farida, Umma. Paradigma Periwayatan Dan Kritik Matan Hadis Perspektif Jamal AlBanna. Yogyakarta: Idea Press, 2009.

Hidayat, Salamah Noor. Kritik Teks Hadis: Analisis Tentang Ar- Riwayah Bil Makna Dan Implikasinya Bagi Kualitas Hadis. Yogyakarta: Teras, 2009.

Imran, Muhammad. "Sahabat Nabi saw Dalam Perspektif Sunni dan Syi'ah (Pengaruhnya Pada Kesahihan Hadis)." Aqlam: Journal of Islam and Plurality 1, no. 1 (2016): 15-34.

Munawir, Ahmad Warson. Al-Munawir: Kamus Arab-Indonesia. Jakarta: Pustaka Progresif, 1984.

Shiddiqy, M. Hasby ash. Pokok- Pokok Ilmu Dirayah Hadits. Jakarta: Bulan Bintang, 1994.

—. Sejarah Dan Pengantar Ilmu Hadis. Semarang: Pustaka Rizki Putra, 2002.

Shihab, M. Quraish. Tafsir al-Mishbah: Pesan, Kesan, dan Keserasian al-Qur'an. Tangerang: Lentera Hati, 2009.

Sochimin, Sochimin. "Telaah Pemikiran Hadis Mahmud Abu Rayyah Dalam Buku "Adwa' 'Ala Al-Sunnah Al-Muhammadiyah"." HUNAFA: Jurnal Studia Islamika 9, no. 2 (2012). doi:10.24239/jsi.v9i2.77.271-300.

Tangngareng, Tasmin. "Telaah Historis Terhadap Keadilan Sahabat." AL-FIKR: Jurnal Pemikiran Islam 14, no. 3 (2010): 447-60.

Yaqub, Ali Mustafa. Kritik Hadis. Jakarta: Pustaka Firdaus, 1996. 